\title{
Motivasi Dan Hasil Belajar Kognitif Siswa Melalui Model Pembelajaran
} Inkuiri Terbimbing

\author{
Dian Safitri ${ }^{1}$, Nurdiyanti ${ }^{2}$, Nurul Fadhilah ${ }^{3}$ \\ 1,2,3Program Studi Pendidikan Biologi, Fakultas Keguruan dan Ilmu Pendidikan, \\ Universitas Muhammadiyah Makassar \\ ${ }^{1}$ Email: dyansafitri87@gmail.com \\ ${ }^{2}$ Email: antinurdiyanti@gmail.com \\ ${ }^{3}$ Email: nurulfadhilahh30@gmail.com
}

\begin{abstract}
Abstrak: Penelitian ini bertujuan untuk mengetahui pengaruh model pembelajaran inkuiri terbimbing terhadap motivasi dan hasil belajar kognitif. Penelitian merupakan eksperimen semu dengan desain pretest-possttest non equivalent control group design. Populasi penelitian adalah seluruh siswa kelas XI Madrasah Aliyah Madani Alauddin Paopao yang berjumlah 95 siswa. Besarnya sampel ditetapkan sebanyak 60 siswa. Penentuan sampel yaitu secara acak kelas. Instrumen penelitian yang digunakan berupa angket motivasi dan tes hasil belajar kognitif. Data dianalisis dengan statistik inferensial analisis kovarian (anakova). Hasil penelitian menunjukkan bahwa penerapan model pembelajaran inkuiri terbimbing berpengaruh secara signifikan terhadap motivasi dan hasil belajar kognitif.
\end{abstract}

\section{Kata Kunci: Motivasi, Hasil Belajar Kognitif, Inkuiri Terbimbing}

Abstract: This study aims to determine the influence of guided inquiry learning model on motivation and cognitive learning outcomes. Research is a quasi experiment with a pretest-possttest nonequivalent control group design. The study population is all students of class XI Madrasah Aliyah Madani Alauddin Paopao which amounted to 95 students. The sample size is set by 60 students. Sample determination is randomly class. The research instrument used in the form of motivation questionnaire and test of cognitive learning result. Data were analyzed by inferential statistics of covariance analysis (ANCOVA). The results showed that the implementation of guided inquiry learning model significantly influence the motivation and cognitive learning outcomes.

\section{Key Words: Motivation, Cognitive Learning Outcomes, Guided Inquiry}

Madrasah Aliyah Alauddin Paopao merupakan salah satu MA yang ada di kabupaten Gowa. Hasil observasi menunjukkan bahwa hasil belajar kognitif di sekolah ini khususnya kelas XI dikatakan masih rendah disebabkan banyak faktor yakni pada saat proses pembelajaran di kelas, guru biologi belum efektif untuk membangkitkan atau menarik motivasi siswa dalam mengikuti proses pembelajaran, siswa merasa bosan dan jenuh mengikuti proses belajar mengajar di kelas sehingga materi yang diajarkan tidak 
dipahami dan dimengerti oleh siswa. Hamalik (2012) menyatakan bahwa motivasi adalah proses membangkitkan, mempertahankan, mengontrol minat-minat yang disediakan oleh lingkungan atau guru dengan maksud merangsang siswa agar belajar lebih giat dan lebih baik. Meskipun guru biologi sudah menerapkan model pembelajaran kooperatif tetapi hanya sebagian siswa yang aktif, yaitu hanya siswa yang cerdas dalam kelompoknya. Sedangkan siswa yang lain hanya diam, mengganggu temannya dan membuat keributan di dalam kelas.

Berdasarkan pengalaman yang ada, proses belajar mengajar biologi di kelas masih didominasi oleh guru, siswa pada umumnya hanya menjadi pendengar baik dan berusaha menulis semua fakta atau konsep, bahkan hanya menghafal semua materi tanpa mampu memahami konsep yang sedang mereka pelajari. Siswa sangat jarang mengajukan pertanyaan atau masalah biologi kepada guru, berinteraksi dengan siswa lain untuk berdiskusi langsung. Kebiasaan-kebiasaan tersebut berakibat pada rendahnya kemampuan pengajuan masalah siswa yang berdampak pada rendahnya hasil belajar siswa. Kegiatan pembelajaran sebagai suatu alternatif dalam upaya peningkatan hasil belajar perlu diupayakan agar lebih bermakna bagi siswa.

Salah satu model pembelajaran yang dapat mengaktifkan siswa dalam belajar adalah model pembelajaran kooperatif yaitu siswa bekerja sama dalam kelompok kecil dan saling membantu dalam belajar (Rijal, M., 2013). Pembelajaran kooperatif merupakan sistem pembelajaran yang memberikan kesempatan kepada siswa untuk bekerja sama dengan siswa dalam tugas-tugas yang terstruktur. Pembelajaan kooperatif dikenal pembelajaran secara kelompok, bahkan belajar kooperatif lebih dari sekedar belajar kelompok atau kerja kelompok karena dalam belajar kooperatif pada struktur atau dorongan atau tugas yang bersifat kooperatif sehingga memungkinkan terjadinya interaksi secara terbuka dan hubungan yang bersifat interdepensi efektif di antara anggota kelompok (Rijal, M. and Sere, I., 2017).

Inkuiri terbimbing terbimbing merupakan salah satu model pembelajaran kooperatif. Lee (2009) menyatakan bahwa pembelajaran inkuiri terbimbing dapat meningkatkan kemampuan memberikan argumen dan membantu siswa untuk terampil dalam memecahkan masalah. Pertanyaan-pertanyaan pada inkuiri terbimbing berkaitan erat dengan keterampilan berpikir. Kemampuan tersebut dapat melatih siswa dalam menggunakan berbagai sudut pandang dalam menyampaikan pendapat. Proses pemikiran yang lebih mendalam menghasilkan argumen berdasarkan bukti dalam memecahkan masalah yang kompleks. Menurut Butler (2011) pembelajaran inkuiri terbimbing telah terbukti melibatkan siswa secara aktif dalam membantu siswa jurusan non-sains dalam belajar dan juga memahami materi-materi lebih dalam. Siswa perlu dilatih melakukan penyelidikan sejak dini dan jika sudah terbiasa dengan kegiatan inkuiri maka penguasaan konsep biologi dan literasi sains akan meningkat (Carlson, 2008). 
Model pembelajaran inkuiri terbimbing bertujuan memberikan cara kepada siswa untuk membangun kecakapan-kecakapan intelektual atau kecakapan berpikir terkait dengan proses-proses berpikir reflektif melalui bimbingan dosen. Menurut Kubicek (2005) pembelajaran berbasis inkuiri dapat meningkatkan pemahaman siswa dengan melibatkannya dalam proses kegiatan pembelajaran secara aktif, sehingga konsep yang dicapai lebih baik. Model pembelajaran inkuiri terbimbing memungkinkan siswa untuk terlibat secara aktif menggunakan proses fisik dalam menemukan sendiri konsep dan prinsip materi yang sedang dipelajari melalui bimbingan dosen. Kegiatan tersebut diyakini tidak hanya mampu untuk menguasai konsep pada materi yang dipelajari tetapi juga membangun sikap ilmiah siswa.

Berdasarkan kajian tersebut model pembelajaran inkuiri terbimbing tepat untuk diterapkan pada matapelajaran Biologi. Proses pembelajaran biologi diperlukan suatu bentuk kegiatan yang dapat melatih siswa untuk dapat menemukan suatu konsep melalui kreativitas secara langsung. Diharapkan melalui penerapan model pembelajaran inkuiri terbimbing dapat terjadi komunikasi aktif secara langsung antara dosen dengan siswa. Hal tersebut dapat mengarahkan perkembangan literasi sains dan penguasaan konsep siswa menuju lebih baik.

\section{METODE PENELITIAN}

Penelitian ini adalah eksperimen semu yang bertujuan untuk mengetahui pengaruh penggunaan penerapan model pembelajaran inkuiri terbimbing terhadap motivasi dan hasil belajar kognitif siswa kelas XI pada materi sistem ekskresi di MA madani Alauddin Paopao. Desain yang digunakan dalam penelitian ini adalah pretest-possttest nonequivalent control group design. Desain tersebutdapat dilihat pada Tabel 1 berikut.

Tabel 1. Desain Penelitian

\begin{tabular}{cccc}
\hline Sampel & Pre test & Perlakuan & Post test \\
\hline XI IPA 1 & $\mathrm{O}_{1}$ & $\mathrm{X}$ & $\mathrm{O}_{2}$ \\
XI IPA 2 & $\mathrm{O}_{3}$ & - & $\mathrm{O}_{4}$ \\
\hline
\end{tabular}

Sumber: Sugiyono (2010)

Populasi penelitian adalah seluruh siswa kelas XI MA Madani Alauddin Paopao yang terdiri dari 3 kelas paralel dengan jumlah siswa secara keseluruhan adalah 95 orang siswa. Besarnya sampel ditetapkan sebanyak 60 responden (masing-masing 30 orang untuk kelompok kontrol dan kelompok eksperimen). Adapun cara penentuan sampel yaitu secara acak kelas, sehingga terpilih kelompok eksperimen dan kelompok kontrol.

Instrumen penelitian yang digunakan adalah Angket (kuesioner) motivasi belajar, yang digunakan untuk memperoleh data motivasi belajar 
siswa. Penilaian dilakukan dengan memberikan tanda cek list $(\sqrt{ })$ pada kolom yang sesuai dengan matriks uraian aspek yang dinilai. Tes hasil belajar kognitif, yang digunakan untuk mengumpulkan data tes hasil belajar kognitif biologi. Data dianalisis dengan statistik inferensial digunakan dalam kaitannya dengan pengujian hipotesis penelitian. Untuk pengujian hipotesis digunakan statistik parametrik dengan menggunakan analisis kovarian (anakova).

\section{HASIL DAN PEMBAHASAN}

\section{Deskripsi Motivasi Siswa dengan Penerapan Model Pembelajaran Inkuiri Terbimbing}

Data hasil perolehan nilai motivasi belajar biologi siswa yang membuktikan adanya peningkatan nilai motivasi belajar biologi siswa kelas IPA 1 MA Madani Alauddin Paopao, sebelum dan sesudah penerapan model pembelajaran Inkuiri terbimbing pada materi sistem ekskresi, dapat dilihat padaTabel 2 berikut.

Tabel 2. Hasil AnalisisAngket Motivasi Belajar Siswa Sebelum dan Sesudah Penerapan

Model Pembelajaran Inkuiri Terbimbing Pada Materi Sistem Ekskresi

\begin{tabular}{lll}
\hline \multirow{2}{*}{ Statistik } & \multicolumn{2}{l}{ Model pembelajaran Inkuiri terbimbing } \\
\cline { 2 - 3 } Subjek & Sebelum & Sesudah \\
Rata-rata & 36 & 36 \\
Median & 64,31 & 71,00 \\
Modus & 64,00 & 72,00 \\
Standar deviasi & 63 & 72 \\
Varians & 5,285 & 5,642 \\
Rentang & 27,933 & 31,829 \\
Nilai terendah & 21 & 22 \\
Nilai tertinggi & 53 & 57 \\
\hline
\end{tabular}

Pada Tabel 2, terlihat bahwa nilai rata-rata motivasi belajar biologi dari 36 siswa kelas IPA 1 MA Madani Alauddin Paopao, meningkat dari sebelum perlakuan dan sesudah perlakuan, yaitu dari 64,31 menjadi 71,00. Nilai terendah untuk motivasi belajar siswa sebelum perlakuan adalah 53 dan nilai tertinggi 74 . Sedangkan setelah perlakuan, nilai motivasi siswa meningkat dengan nilai terendah 57 dan nilai tertinggi 79. 


\section{Deskripsi Motivasi Siswa dengan Penerapan Model Pembelajaran Konvensional}

Hasil perolehan data motivasi belajar biologi siswa, yang membuktikan adanya peningkatan nilai motivasi belajar biologi siswa sebelum dan sesudah diajar dengan model pembelajaran Konvensional, dapat dilihat pada Tabel 3 berikut.

Tabel 3. Hasil Analisisangket Motivasi Belajar Siswa Sebelum Dan Sesudah Diajar

Dengan Penerapan Model Pembelajaran Konvensional

\begin{tabular}{lll}
\hline \multirow{2}{*}{ Statistik } & \multicolumn{2}{l}{ Model Konvensional } \\
\cline { 2 - 3 } & Sebelum & Sesudah \\
\hline Subjek & 37 & 37 \\
Rata-rata & 62,00 & 68,16 \\
Median & 63,00 & 68,00 \\
Modus & 66 & 66 \\
Standar deviasi & 6,272 & 5,914 \\
Varians & 39,333 & 34,933 \\
Rentang & 24 & 28 \\
Nilai terendah & 50 & 51 \\
Nilai tertinggi & 74 & 79
\end{tabular}

Pada Tabel 3 terlihat bahwa nilai rata-rata motivasi belajar biologi dari 37 siswa kelas XI IPA 2 di MA Madani Alauddin Paopao, meningkat dari sebelum dan sesudah perlakuan, yaitu dari 62,00 menjadi 68,00. Nilai terendah untuk motivasi belajar biologi siswa sebelum perlakuan adalah 50 dan nilai tertinggi adalah 74 . Sedangkan setelah perlakuan, nilai motivasi siswa meningkat dengan nilai terendah adalah 51 dan nilai tertinggi adalah 79 .

Analisis Statistik Deskriptif Hasil Belajar Siswa yang Diajar melalui penerapan Model Pembelajaran Inkuiri terbimbing

Hasil analisis statistik deskriptif berdasarkan skor hasil belajar yang diperoleh siswa pada materi sistem ekskresi di kelas XI IPA 1 MA Madani Alauddin Paopao dengan menggunakan model pembelajaran Inkuiri terbimbing dapat dilihat pada Tabel 4 berikut. Tabel 4. Hasil Analisis Statistik Deskriptif Nilai Hasil Belajar Siswa Dengan

Menggunakan Model Pembelajaran Inkuiri Terbimbing

\begin{tabular}{lll}
\hline \multirow{2}{*}{ Statistik } & \multicolumn{2}{c}{$\begin{array}{r}\text { Model pembelajaran Inkuiri } \\
\text { Terbimbing }\end{array}$} \\
\cline { 2 - 3 } & Pre Test & Post Test \\
\hline Subjek & 36 & 36 \\
Rata-rata & 47,71 & 72,78
\end{tabular}




$\begin{array}{llc}\text { Median } & 48,75 & 75,00 \\ \text { Modus } & 35,00 & 85,00 \\ \text { Standar deviasi } & 10,545 & 10,620 \\ \text { Varians } & 111,205 & 112,778 \\ \text { Rentang } & 40,00 & 35,00 \\ \text { Nilai terendah } & 25,00 & 53,00 \\ \text { Nilai tertinggi } & 65,00 & 88,00\end{array}$

Berdasarkan Tabel 4, dapat diketahui bahwa hasil belajar siswa kelas XI IPA 1 sebelum diajar dengan menggunakan model pembelajaran Inkuiri terbimbing menunjukkan nilai tertinggi adalah 65 dan nilai terendah adalah 25. Adapun nilai ratarata yang diperoleh adalah 47,71, sedangkan hasil belajar siswa setelah diajar dengan model pembelajaran Inkuiri terbimbing menunjukkan nilai tertinggi adalah 88 dan nilai terendah adalah 53. Nilai rata-rata yang diperoleh pun mengalami peningkatan, yakni menjadi 72,78 .

\section{Analisis Statistik Deskriptif Hasil Belajar Siswa yang Diajar dengan model pembelajaran Konvensional}

Hasil analisis statistik deskriptif yang didasarkan pada nilai hasil belajar kognitif biologi yang diperoleh siswa kelas XI IPA $\mathrm{P}_{2}$ di MA Madani Alauddin Paopao pada materi sistem ekskresi dengan menggunakan model pembelajaran konvensional, dapat dilihat pada Tabel 5 berikut.

Tabel 5. Hasil Analisis Statistik Deskriptif Nilai Hasil Belajar Siswa yang Diajar dengan

Model Pembelajaran Model Konvensional

\begin{tabular}{lll}
\hline \multirow{2}{*}{ Statistik } & \multicolumn{2}{l}{ Model Konvensional } \\
\cline { 2 - 3 } & Pre Test & Post Test \\
\hline Subjek & 37 & 37 \\
Rata-rata & 42,70 & 53,04 \\
Median & 42,50 & 50,00 \\
Modus & 35,00 & 40,00 \\
Standar deviasi & 8,846 & 13,567 \\
Varians & 78,256 & 184,075 \\
Rentang & 33,00 & 50,00 \\
Nilai terendah & 28,00 & 28,00 \\
Nilai tertinggi & 60,00 & 78,00 \\
\hline
\end{tabular}


Berdasarkan Tabel 5, dapat diketahui bahwa hasil belajar kognitif biologi dari 37 siswa kelas XI IPA2 2 sebelum diajar tanpa model pembelajaran Inkuiri terbimbing atau Model Konvensional menunjukkan nilai tertinggi adalah 60 dan nilai terendah adalah 28. Nilai rata-rata yang diperoleh adalah 42,70. Sedangkan hasil belajar dari 37 siswa setelah diajar dengan model Konvensional menunjukkan nilai tertinggi adalah 78 dan nilai terendah adalah 28 . Nilai rata-rata yang diperoleh setelah perlakuan meningkat menjadi 53,04 .

Analisis Statistik Inferensial Nilai Motivasi Belajar Biologi Siswa yang Diajar dengan Model Inkuiri terbimbing dan Siswa yang Diajar dengan Model Konvensional

Nilai hasil analisis kovarian untuk data motivasi belajar biologi siswa dapat dilihat pada Tabel 6 berikut.

Tabel 6 NilaiHasil Analisis Kovarian Data Motivasi Belajar Biologi Siswa

\begin{tabular}{ll}
\hline Nilai Signifikansi Hitung & Nilai Signifikansi Tabel \\
\hline 0,000 & 0,05 \\
\hline
\end{tabular}

Berdasarkan Tabel 6, jelas terlihat bahwa nilai sig. hitung $(0,000)<$ sig. $\alpha(0,05)$, berarti $\mathrm{H}_{0}$ ditolak. Jadi, terdapat perbedaan yang signifikan antara motivasi belajar biologi siswa pada kelas kontrol dengan kelas eksperimen. Hal ini dikuatkan dengan nilai estimasi parameter kelas kontrol adalah -8,344, sedangkan kelas eksperimen adalah 0 . Jadi, estimasi parameter kelas eksperimen lebih besar daripada estimasi parameter kelas kontrol $(0>-8,344)$, yang menunjukkan bahwa nilai motivasi belajar biologi siswa yang diajar dengan penerapan model pembelajaran kooperatif Inkuiri terbimbing lebih tinggi sebesar 8,344 satuan daripada siswa yang diajar dengan Penerapan model pembelajaran konvensional pada materi sistem ekskresi.

Analisis Statistik Inferensial Hasil Belajar Siswa yang Diajar dengan Model Pembelajaran Inkuiri terbimbing dan Siswa yang Diajar dengan Model Pembelajaran konvensional

Nilai hasil analisis kovarian untuk data hasil belajar kognitif biologi siswa dapat dilihat pada Tabel 7 berikut.

Tabel 7. NilaiHasil Analisis Kovarian Data Hasil belajar kognitif biologi Siswa

\begin{tabular}{ll}
\hline Nilai Signifikansi Hitung $(\mathrm{p})$ & Nilai Signifikansi $\alpha$ \\
\hline 0,000 & 0,05
\end{tabular}

Berdasarkan hasil pengujian pada Tabel 7 di atas,jelas terlihat bahwa nilai sig. hitung $(0,000)<$ sig. $\alpha(0,05)$, yang berarti $\mathrm{H}_{0}$ ditolak. Jadi, terdapat perbedaan yang signifikan antara hasil belajarbiologi siswa pada kelas kontrol dengan kelas eksperimen. Hal ini dikuatkan dengan nilai estimasi parameter kelas kontrol adalah -18,169, sedangkan kelas eksperimen adalah 0. Jadi, estimasi parameter kelas eksperimen lebih besar daripada estimasi parameter kelas kontrol $(0>-18,169)$, yang menunjukkan bahwa nilai hasil belajar kognitif biologi siswa yang diajar dengan penerapan model pembelajaran inkuiri terbimbinglebih tinggi sebesar 18,169 daripada nilai hasil belajar 
kognitif biologi siswa yang diajar dengan Penerapan model konvensional pada materi sistem ekskresi.

Hasil analisis deskriptif data menunjukkan nilai rata-rata motivasi belajar biologi dari 36 siswa kelas XI IPA 1 di MA Madani Alauddin Paopao yang diajar dengan Penerapan model pembelajaran Inkuiri terbimbing pada materi sistem ekskresi (kelas eksperimen) mengalami peningkatan sebesar 12,92. Motivasi belajar biologi siswa setelah perlakuan didominasi oleh siswa dengan kategori motivasi tinggi dan tinggi sekali. Adapun nilai rata-rata motivasi belajar biologi siswa kelas XI IPA 2 yang diajar dengan penerapan model pembelajaran konvensional (kontrol) mengalami peningkatan sebesar 24,93. Hasil dari kedua perlakuan tersebut mengindikasikan bahwa penerapan model pembelajaran inkuiri terbimbingmampu meningkatkan motivasi belajar siswa. Hal tersebut juga diperkuat oleh hasil analisis inferensial melalui uji SPSS yang menunjukkan bahwa terdapat perbedaan dan pengaruh pada nilai motivasi belajar biologi siswa yang signifikan antara kelas dengan Penerapan model pembelajaran Inkuiri terbimbing pada materi sistem ekskresi dan kelas dengan penerapan model pembelajaran konvensional.

Nilai motivasi belajar biologi siswa setelah perlakuan dikelas dengan Penerapan model pembelajaran Inkuiri terbimbing pada materi sistem ekskresi (eksperimen) memiliki nilai yang lebih rendah sebesar 8,344 dibanding dengan kelas dengan penerapan model pembelajaran konvensional (kontrol). Ini berarti bahwa penerapan model pembelajaran Inkuiri terbimbing lebih baik daripada Penerapan model pembelajaran konvensional pada materi sistem ekskresi, serta lebih mampu meningkatkan motivasi belajar biologi siswa, khususnya pada pokok bahasan sistem ekskresi.

Hal tersebut sejalan dengan teori yang dikemukakan oleh Trianto (2007), bahwa berdasarkan hasil analisis penelitian terhadap rendahnya motivasi belajar peserta didik, hal tersebut ternyata disebabkan proses pembelajaran yang masih didominasi oleh pembelajaran tradisional, misalnya dengan metode ceramah yang cenderung membuat siswa menjadi kurang aktif.

Motivasi belajar biologi siswa di kelas kontrol setelah perlakuan didominasi oleh siswa dengan kategori motivasi tinggi sedangkan pada kelas eksperimen didominasi oleh siswa dengan kategori motivasi tinggi sekali. Ini menunjukkan bahwa penerapan model pembelajaran Inkuiri terbimbing dapat meningkatkan nilai rata-rata motivasi belajar biologi siswa dan mampu meningkatkan jumlah siswa yang termasuk ke dalam kategori motivasitinggi sekali. Hal tersebut sejalan dengan hasil penelitian Saham (2013), bahwa model pembelajaran inkuiri terbimbingdapat meningkatkan motivasi belajar siswa.

Siswa yang belajar menggunakan model pembelajaran kooperatif akan memiliki motivasi yang tinggi karena didorong dan didukung oleh rekan sebaya. Lie (2004), menyatakan bahwa pembelajaran kooperatif dapat meningkatkan motivasi belajar siswa, menghasilkan peningkatan kemampuan akademik, dan kemampuan berpikir kritis. Sejalan dengan Hamalik (2012), menyatakan bahwa tekanan kelompok murid 
kebanyakan lebih efektif dalam memotivasi daripada tekanan/paksaan dari orang lain. Murid akan bersedia melakukan apa yang akan dilakukan oleh grupnya dan demikian sebaliknya.

Pada model pembelajaran inkuiri terbimbing perbedaan kebutuhan peserta didik untuk mencapai tujuan belajar yang maksimal menjadi pertimbangan yang utama. Adanya pembelajaran yang dirancang untuk mengakomodasi kemampuan dan kebutuhan siswa ini diharapkan dapat mengatasi kesulitan yang dialami siswa, sehingga motivasi belajarnya meningkat. Levine (2002) menyatakan bahwa inkuiri terbimbing menekankan siswa pada inti dari belajar. Secara filosofis, setiap siswa berbeda, sehingga DI menekankan bahwa satu model pembelajaran tidak dapat mengakomodasi keberagaman setiap siswa, terutama ketika model yang diterapkan oleh guru tidak cocok dengan siswanya. Pembelajaran inkuiri terbimbing memungkinkan semua siswa untuk mengakses kurikulum kelas yang disesuaikan dengan kebutuhan siswa.

Hasil analisis deskriptif menunjukkan nilai rata-rata hasil belajar kognitif biologi siswa kelas XI IPA 1 di MA Madani Alauddin Paopao yang diajar dengan Penerapan model pembelajaran Inkuiri terbimbing pada materi sistem ekskresi (eksperimen) mengalami peningkatan sebesar 17,28. Sementara itu, nilai rata-rata hasil belajar kognitif biologi siswa kelas XI IPA 2 yang diajar dengan menerapkan model pembelajaran konvensional mengalami peningkatan sebesar 42,44. Hal tersebut mengindikasikan bahwa penerapan model pembelajaran Inkuiri terbimbing mampu meningkatkan hasil belajar kognitif biologi, khususnya hasil belajar kognitif biologi siswa.

Hal tersebut sejalan dengan teori yang dikemukakan oleh Trianto (2007), bahwa berdasarkan hasil analisis penelitian terhadap rendahnya hasil belajar peserta didik, hal tersebut ternyata disebabkan proses pembelajaran yang didominasi oleh pembelajaran tradisional, misalnya dengan metode ceramah yang cenderung membuat siswa menjadi kurang aktif (Rijal, Muhammad, 2018).

Meskipun demikian, tidak semua siswa yang memiliki motivasi tinggi berbanding lurus dengan nilai hasil belajarnya. Ada beberapa siswa yang memiliki motivasi lebih rendah dari siswa lain tetapi memiliki nilai hasil belajar yang lebih tinggi. Ini menunjukkan bahwa meskipun motivasi berprestasi siswa tinggi, tetapi jika tidak ditunjang oleh faktor lain misalnya kompetensi guru dalam mengajar, sarana dan prasarana sekolah khususnya mata pelajaran biologi (menyangkut kenyamanan siswa dalam belajar dan memahami setiap bab yang diajarkan). Ditambah lagi dengan banyaknya hari libur dan kegiatan sekolah yang membuat jadwal pelajaran terganggu. Sehingga pembelajaranpun tidak berlangsung sesuai dengan jadwal. Hal ini menyebabkan ada kelas yang kurang mendapatkan pendalaman materi. Fenomena ini membuktikan keterkaitan antara faktor internal dan eksternal sangat mempengaruhi hasil belajar. Sejalan dengan hal tersebut, Slameto (2003), menyatakan bahwa hasil belajar dipengaruhi oleh beberapa faktor, yakni faktor dari dalam (faktor internal) dan dari luar 
(faktor eksternal). Faktor internal adalah faktor jasmaniah, psikologis, dan faktor kelelahan (misalnya, intelegensi, perhatian, minat, bakat, motivasi, kematangan, kesiapan), sedangkan yang termasuk faktor eksternal adalah faktor keluarga, faktor sekolah, dan faktor masyarakat (misalnya guru, kurikulum, dan model pembelajaran). Sedangkan Sopah, (2000), mengemukakan tiga faktor utama yang memengaruhi hasil belajar, yaitu kemampuan kognitif, motivasi berprestasi, dan kualitas pembelajaran. Data hasil belajar siswa yang masuk kategori sedang, sedangkan motivasi belajarnya tinggi, tetap membuktikan bahwa motivasi belajar memberikan kontribusi positif terhadap hasil belajar. Jika seseorang memiliki motivasi berprestasi yang tinggi maka hasil belajarnya akan semakin tinggi tentunya tetap ditunjang dengan faktor eksternal.

Penggunaan model pembelajaran inkuiri terbimbing dalam pelajaran biologi tidak hanya meningkatkan hasil belajar siswa tetapi juga mengembangkan keterampilan sosial siswa selama proses pembelajaran. Hal ini didukung oleh pendapat Ibrahim (2005) bahwa model pembelajaran kooperatif dikembangkan untuk mencapai setidak-tidaknya tiga tujuan pembelajaran penting, yaitu hasil belajar akademik, penerimaan terhadap perbedaan individu, dan pengembangan keterampilan sosial.

\section{KESIMPULAN}

Kesimpulan dari penelitian ini: (1) Penerapan model pembelajaran inkuiri terbimbing berpengaruh secara signifikan terhadap motivasi belajar biologi siswa. Motivasi belajar biologi siswa yang diajar dengan penerapan model pembelajaran inkuiri terbimbing lebih baik daripada motivasi belajar biologi siswa yang diajar dengan penerapan model pembelajaran konvensional, dan (2) Penerapan model pembelajaran inkuiri terbimbing berpengaruh secara signifikan terhadap hasil belajar biologi siswa. Hasil belajar biologi siswa yang diajar dengan penerapan model pembelajaran inkuiri terbimbing lebih baik dari pada hasil belajar biologi siswa yang diajar dengan penerapan model pembelajaran konvensional.

\section{DAFTAR PUSTAKA}

Buttler, D, 2011. Getting Going with Autograph 3, Eastmond Publishing Ltd, UK

Carlson, J. L. 2008. Effect of Theme-based Guided Inquiry Instruction on Science Literacy in Ecology. (Thesis). Michigan Tecnological University. Washington DC.

Hamalik, O. 2012. Strategi Belajar Mengajar Berdasarkan CBSA. Bandung: CV Sinar Baru.

Ibrahim. 2000. Pembelajaran Kooperatif Pusat Sains dan Matematika Sekolah Program Pasca Sarjana Unesa. Surabaya: University Press. 
Kubicek, J.P. 2005. Inquiry-Based Learning, The Nature of Science, and Computer Technology: New Possibilities in Science Education. Canadian Journal of Learning and Technology. 31(1):1-10.

Lee, M. 2009. The Effect of Guided Inquiry Laboratory on Conceptual Understanding.

Tesis. (Online). California State University, Northridge.

Levine, M. 2002. A Mind at a Time. New York: Simon \& Schuster.

Lie, A. 2004. Cooperatif Learning Mempratekkan Cooperative Learning di Ruang-Ruang Kelas. Jakarta: Grasindo.

Rijal, M. and Sere, I., 2017. SARANA BERFIKIR ILMIAH. Biosel: Biologi Science and Education, 6(2), pp.176-185.

Rijal, M., 2018. PENERAPAN MODEL PEMBELAJARAN KOOPERATIF TIPE NUMBERED HEADS TOGETHER DALAM MENINGKATKAN AKTIVITAS DAN HASIL BELAJAR COGNITIF SISWA KELAS VIII DI SMP NEGERI 14 AMBON. Jurnal BIOEDUIN: Program Studi Pendidikan Biologi, 8(2), pp.6-16.

Rijal, M., 2013. MODEL STAD (STUDIENT TEAMS ACHIEVEMENT DEVISION) DALAM MENINGKATKAN HASIL BELAJAR COGNITIF SISWA. Biosel: Biologi Science and Education, 2(2), pp.150-158

Saham, C. 2013. Peningkatan Motivasi, Aktivitas, dan Hasil Belajar Kognitif Biologi dengan Menggunakan Model Pembelajaran Two Stay Two Stray Pada Materi Kelangsungan Hidup Organisme Siswa Kelas IX 2 SMP Negeri 3 Sungguminasa. Tesis Tidak diterbitkan. Makassar: Program Pascasarjana Universitas Negeri Makassar.

Slameto. 2003. Belajar dan Faktor-Faktor yang Mempengaruhinya. Jakarta: Rineka Cipta.

Sopah, J. 2000. Pengaruh Model Pembelajaran dan Motivasi Berprestasi Terhadap Hasil Belajar. Jurnal Pendidikan dan Kebudayaan, (online), jilid 1, No. 22.

Sugiyono. 2010. Metode Penelitian Pendidikan Pendekatan Kuantitatif, kualitatif, dan R\&D. Bandung: Alfabeta

Trianto. 2010. Mendesain Model Pembelajaran Inovatif-Progresif. Jakarta: Kencana. 